\title{
SISTEM PENDUKUNG KEPUTUSAN PENYEDIA DOKUMEN DALAM PENGAJUAN SERTIFIKASI HALAL MENURUT LPPOM-MUI
}

\section{DECISION SUPPORT SYSTEM DOCUMENT PROVIDERS IN HALAL CERTIFICATION SUBMISSION ACCORDING TO LPPOM-MUI}

\author{
Siti Ulfah Fauziah ${ }^{1)}$, Kudang Boro Seminar ${ }^{2 *}$, Irman Hermadi ${ }^{3)}$, Nugraha Edhi Suyatma ${ }^{4}$ \\ ${ }^{1)}$ Program Studi Ilmu Komputer, Fakultas Matematika dan Ilmu Pengetahuan, Institut Pertanian Bogor, Indonesia \\ ${ }^{2)}$ Departemen Tenik Mesin dan Biosistem, Fakultas Teknologi Pertanian, Institut Pertanian Bogor, Indonesia \\ E-mail: seminarkudangboro@gmail.com \\ ${ }^{3)}$ Departemen Ilmu Komputer, Fakultas Matematika dan Ilmu Pengetahuan, Institut Pertanian Bogor, Indonesia \\ ${ }^{4)}$ Departemen Ilmu dan Teknologi Pangan, Fakultas Teknologi Pertanian, Institut Pertanian Bogor, Indonesia
}

Makalah: Diterima 3 Juli 2017; Diperbaiki 20 November 2017; Disetujui 2 Desember 2017

\begin{abstract}
Halal certification is a form of moslem consumer protection to solve halal problems. Acceleration of the submission process depends on accuration and completeness of the proposed requirements document. This research objective was to accelerate the registration process of halal certification, especially on data entry phase of materials which applied into decision support system. Decision support system can be used to determining the supporting documents of materials types. Input to the decision support system were names of materials from the products to be certified. The decision support output came from integration of decision tree analysis with $\mathrm{J} 48$ model and critical points of materials which resulted 43 rules. The output from this system consisted of flow process diagram, technical specifications, COA (Certificate of Analysis) or material purchase documents, halal certificate, and blank document. The decision support system had been developed into webbased system using hypertext preprocessor (PHP) programming language and MySQL (My Structured Query Language) database management system.
\end{abstract}

Keywords: decision support system, decision tree halal certification, supporting document of materials, web base

\section{ABSTRAK}

Sertifikasi halal merupakan salah satu bentuk perlindungan terhadap konsumen muslim dalam mengatasi masalah halal. Cepat atau lambatnya proses pengajuan sertifikasi halal bergantung pada ketepatan dan kelengkapan dokumen persyaratan yang diajukan. Penelitian ini dilakukan dengan tujuan untuk mempercepat proses pendaftaran sertifikasi halal, khususnya dalam tahap pengisian data bahandengan menerapkansistem pendukung keputusan. Sistem pendukung keputusan digunakan untukmembantu prosespenentuan jenis dokumen pendukung bahan. Input yang diberikan kepada sistem pendukung keputusan berupa nama-nama bahan dari produk yang akan disertifikasi. Dukungan keputusan yang dihasilkan sistem berasal daripenggabungan analisis pohon keputusan model J48 dengan aturan penentuan kategori titik kritis bahan, yang menghasilkan 43 aturan keputusan. Jenis dokumen pendukung yang menjadi keluaran dari sistem pendukung keputusan ini terdiri atas diagram alir proses, spesifikasi teknis, COA (Certificate of Analysis) atau dokumen pembelian bahan, sertifikat halal dan dokumen kosong. Sistem pendukung keputusan ini telah dikembangkan ke dalam sistem berbasis web dengan menggunakan bahasa pemrograman hypertext prepocessor (PHP) dan database management system MySQL (My Structured query language).

Kata kunci: dokumen pendukung bahan, sistem pendukung keputusan, sertifikasi halal, pohon keputusan, berbasis web

\section{PENDAHULUAN}

Indonesia merupakan negara yang mayoritas penduduknya beragama Islam, tercatat sejumlah $87,18 \%$ dari total keseluruhan yang berjumlah 237.641.326 orang (BPS, 2015). Islam memiliki prinsip mengenai kesucian, kebersihan, keamanan dan kesehatan, yang dikenal sebagai konsep halal. Saat ini berbagai permasalahan halal muncul dan menjadi isu penting yang menjadi fokus perhatian diberbagai bidang. Salah satu permasalahan halal menurut Rajagopal et al. (2011) disebabkan oleh pengetahuan konsumen Muslim mengenai produk yang telah bersertifikasi halal masih sangat rendah. Pada penelitian Salehudin dan Mukhlish (2012) diketahui bahwa masalah tersebut dapat mempengaruhi pemasaran produk halal. Cara mengatasinya adalah dengan melakukan edukasi terhadap konsumen muslim secara aktif terkait pemahaman hukum halal-haram dan kemampuan individu untuk mengenali apa saja yang diharamkan dalam islam.

Permasalahan halal tidak hanya pada produk yang dikonsumsi saja tetapi juga pada 
logistik halal (Iberahim et al., 2012). Penyebab permasalahan logistik halal, antara lain kurangnya otoritas sertifikasi halal, integritas halal, masalah yang berkaitan dengan proses sertifikasi halal, isu transparansi, dan kurangnya penyedia layanan logistik halal yang bersertifikat (Tieman, 2011). Sertifikasi halal merupakan suatu proses yang terdiri atas rangkaian kegiatan pengujian untuk menentukan status kehalalan suatu produk berdasarkan bahan dan proses produksinya. Badan yang mengatur sertifikasi halal di Indonesia adalah Lembaga Pengkajian Pangan, Obat-Obatan dan Kosmetika Majelis Ulama Indonesia (LPPOM MUI).

Salah satu bentuk perlindungan terhadap konsumen Muslim dan penyelesaian masalah halal di Indonesia adalah ditetapkannya Undang-undang No.33 Tahun 2014 atau yang dikenal dengan Undang-undang jaminan produk halal (UU JPH). Saat UU JPH resmi diberlakukan 2019 mendatang, setiap produk yang masuk, beredar dan diperdagangkan di Indonesia wajib memiliki sertifikat halal. Namun pemberlakuan UU tersebut dapat memberikan dampak bagi pengusaha yang produknya belum tersertifikasi.

Sejak Juni 2012 LPPOM MUI telah memberikan kemudahan dalam pengajuan sertifikasi halal secara online menggunakan sistem Cerol di halaman www.e-lppommui.org (E-Halal Registration, 2014). Tidak ada batasan waktu pendaftaran sertifikasi halal karena proses pengisian data dapat dilakukan secara bertahap (MUI, 2014). Cepat atau lambatnya proses pendaftaran sertifikasi halal bergantung pada ketepatan dan kelengkapan dokumen persyaratan yang diajukan. Pada proses pendaftaran sertifikasi halal, terdapat pengisian data bahan dalam tahap upload data sertifikasi. Perusahaan harus melampirkan dokumen pendukung bahan yang digunakan. Namun saat ini pada panduan penggunaan Cerol belum ada penjelasan mengenai dokumen bahan yang perlu dilampirkan saat mendaftarkan sertifikasi halal produk. Perusahaan kesulitan menentukan dokumen pendukung bahan yang tepat untuk dilampirkan produknya. Keterlambatan ataupun kesalahan dalam menentukan dan melampirkan dokumen pendukung bahan dapat memperpanjang waktu proses berkas permohonan pendaftaran sertifikasi. Proses pengambilan keputusan sering kali dihadapkan pada berbagai kondisi yang tidak pasti, bahkan memakan waktu yang lama.

Tujuan penelitian ini adalah menentukan parameter penentuan dokumen pendukung bahan yang tepat dan menerapkannya ke dalam Sistem pendukung keputusan (SPK). SPK berfungsi mentransformasi data dan informasi menjadi alternatif keputusan dan prioritasnya (Marimin dan Maghfiroh, 2010). Menurut Moussaet al. (2004) salah satu alat yang paling atraktif dan mudah yang dapat digunakan dalam pembuatan keputusan adalah pohon keputusan. Metode pohon keputusan model J48 diketahui mampu memberikan hasil terbaik berdasarkan kriteria tingkat akurasi, jumlah dan panjang rule yang dihasilkan dan ROC atau tingkat falsepositive rendah dan truepositif tinggi dalam menentukan kehalalan produk olahan susu (Abu et al., 2013). Melalui penerapan metode serupa Ahsyar et al. (2015) menghasilkan rule keputusan penentuan kemasan produk daging dengan nilai akurasi sempurna $100 \%$.

Penelitian untuk menyelesaikan masalah proses sertifikasi telah dilakukan Fauzi et al. (2014) sebelumnya dengan merancang prototype sistem $e$ service untuk pendaftaran sertifikasi halal di Kabupaten Bogor dan memberikan informasi produk halal. Namun e-service tersebut belum mengacu dan terintegrasi sistem perdaftaran online/Cerol LPPOM MUI. Pada penelitian lain, penerapan teknologi latent semantic indexing (LSI) digunakan untuk temu kembali informasi yang diaplikasikan pada sistem pencarian dokumen halal Malaysia (Hanum et al., 2012), sedangkan kualitas informasi dipengaruhi oleh kepercayaan, fitur, privasi, keamanan dan informatif (Samsi et al., 2011).

Penerapan pelitian ini merujuk pada tujuan dan fungsi yang telah diterapkan pada penelitian sebelumnya dengan penentuan aturan pengambilan keputusan berdasarkan penerapan metode pohon keputusan model J48. Melalui penerapan SPK ini diharapkan dapat mempermudah perusahaan dalam memperoleh informasi mengenai dokumen pendukung bahan yang tepat untuk produknya saat ini sehingga dapat meningkatkan kesiapan perusahaan dan mempercepat waktu pendaftaran sertifikasi halal.

\section{METODE PENELITIAN}

Penelitian ini dilakukan pada April 2016 di laboratorium Software Engineering and Information SciencesInstitut Pertanian Bogor. Pada Gambar 1 dijelaskan tahapan penelitian ini diawali dengan tahap identifikasi masalah yang terjadi seputar proses pengajuan sertifikasi halal untuk mendapatkan permasalahan yang akan diselesaikan, perumusan masalah, penentuan tujuan dan manfaat yang akan dicapai, batasan penelitian, pengkajian pustaka, pengumpulan data sertifikasi halal, data bahan, data dokumen pendukung dari bahan yang sudah didokumentasikan sebelumnya, serta metode penyelesaian masalah dari berbagai sumber artikel, jurnal, buku, situs web site serta diskusi pakar. Data yang telah terkumpul selanjutnya dipraproses dan selanjutnya diproses kembali pada tahap analisis. Tahap perencanaan sistem dilakukan menggunakan konteks diagram untuk mendapatkan gambaran umum sistem yang akan dikembangkan. 


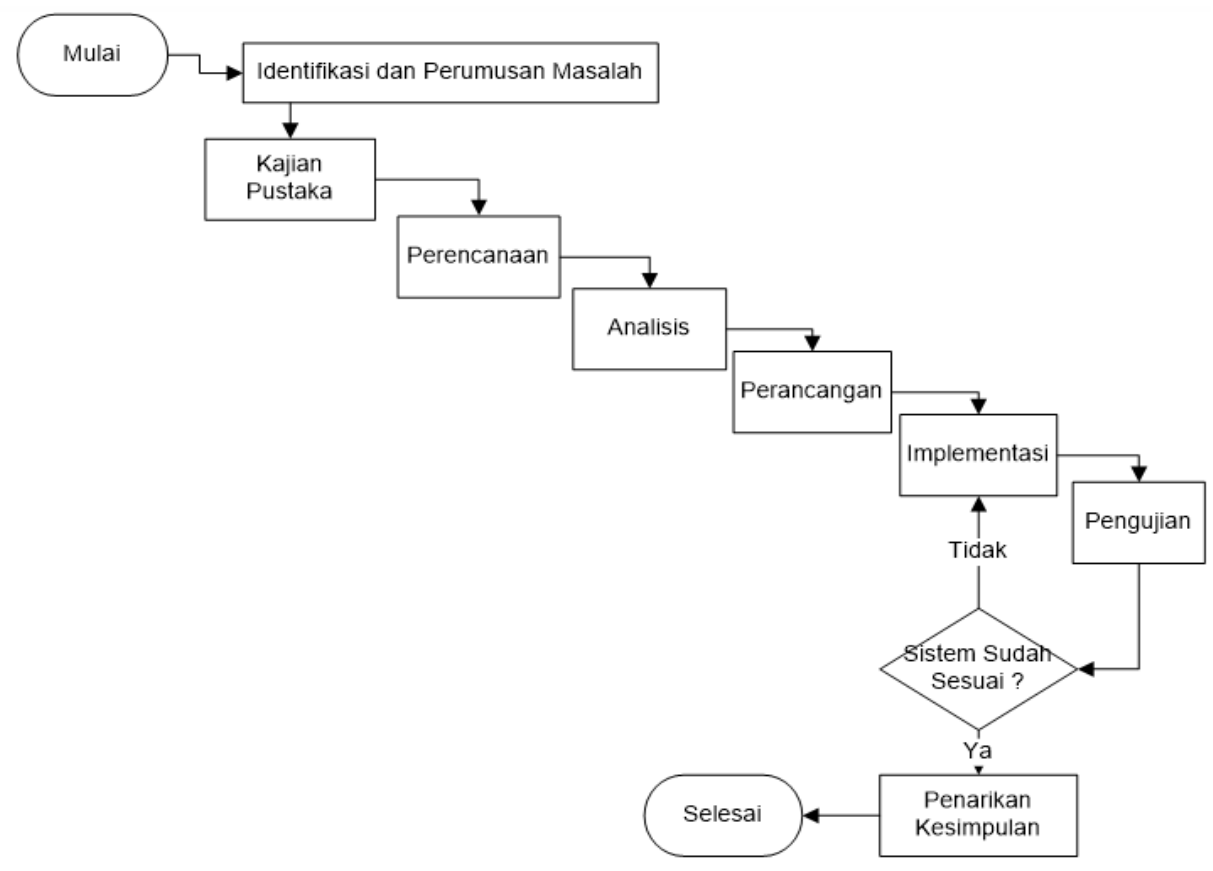

Gambar 1. Tahapan penelitian

Tahapan analisis, terdiri atas analisis data pemilihan dokumen bahan dan analisis kebutuhan sistem. Analisis data dilakukan menggunakan perangkat lunak Weka versi 3.6.12 untuk mendapatkan parameter penentu keputusandan Microsoft Excel untuk mengetahui detail pembentukan pohon keputusan yang dihasilkan. Aturan pohon keputusan yang dihasilkan selanjutnya digabungkan aturan penentuan kategori titik kritis bahan dan diverifikasi kepada pakar sebelum diimplementasikan kedalam sistem. Analisis kebutuhan sistem dilakukan dengan membuat pemodelan DFD dan ERD, menggunakan perangkat lunak Microsoft Office Visio.

Tahapan perancangan antar muka sistem dilakukan menggunakan Balsamiq Mockups 3. Pada tahap implementasi sistem dilakukan penerapan aturan dukungan pengambilan keputusan yang telah dihasilkan pada tahap analisis ke dalam bahasa pemrograman PHP dan database management system MySQL. Hasil yang diperoleh dari tahap ini adalah sistem pendukung keputusan penentu dokumen bahan (SPK PDPB) yang dapat menentukan dokumen pendukung bahan pada tahap pengisian data bahan, melakukan pencarian informasi data bahan, jenis dokumen pendukung bahan dan sertifikasi halal dan juga dapat menampung aspirasi pengunjung website berdasarkan komentar pengguna.

Tahap terakhir dari penelitian ini adalah pengujian sistem secara fungsional dan verifikasi. Pengujian fungsional sistem dilakukan menggunakan metode pengujian black box. Sedangkan tahap verifikasi dilakukan dengan konfirmasi output yang dihasilkan sistem kepada pakar.

\section{HASIL DAN PEMBAHASAN}

\section{Praproses Data}

Tahap praproses data ini melibatkan peranan pakar dalam menentukan parameter dan atribut yang tepat untuk menghasilkan dukungan keputusan yang sesuai. Pada tahap awal praproses dilakukan pembuatan pohon keputusan dengan menggunakan data bahan asli yang didapatkan pada tahap pengumpulan data. Data tersebut terdiri atas 3 parameter, yaitu sumber bahan baku, titik kritis dan kode nama $E$ number. Namun dukungan keputusan yang dihasilkan dari pohon keputusan tersebut tidak sesuai dengan yang diinginkan pakar, oleh karena itu dilakukan klasifikasi data atribut dan penentuan parameter baru dari data sebelumnya. Misalnya, pada data awal parameter sumber bahan baku pada Sample 1 berasal dari kayu, Sample 2 berasal dari alga, sedangkan Sample 3 berasal dari lemak nabati. Setelah dilakukan praproses, atribut dari parameter pada Sample 1, 2 dan 3 diklasifikasikan menjadi sumber bahan baku nabati. Hasil akhir praproses data terdiri atas 5 parameter, yaitu sumber bahan baku, proses tambahan, sumber bahan tambahan, titik kritis bahan dan jenis bahan tambahan. Penentuan parameter baru tersebut mengacu pada aturan penentuan titik kritis bahan. Selanjutnya dilakukan perulangan proses pembentukan pohon keputusan menggunakan data baru yang dihasilkan. Setelah hasil dari pohon keputusan tersebut disesuai dengan pendapat pakar maka data tersebutlah yang akan digunakan kembali pada tahap analisis data.

\section{Perencanaan}

Perencanaan sistem dituangkan ke dalam model context diagram untuk menggambarkan ruang 
lingkup dari sistem dan aliran informasi yang keluarmasuk pada sistem atau pertukaran infromasi antara pengguna dengan sistem, sehingga dapat mempermudah pemahaman proses bisnis yang diinginkan dan keterlibatan pengguna. Ruang lingkup proses yang ada pada sistem pendukung keputusan penentu dokumen pendukung bahan ini dapat dilihat pada Gambar 2.

\section{Analisis Pemilihan Dokumen Pendukung Bahan}

Data yang dihasilkan dari tahap praproses data terdiri dari 738 sample data, selanjutnya dibagi menjadi $80 \%$ data latih dan $20 \%$ data uji. Data tersebut kemudian diproses menggunakan algoritme pohon keputusan J48 dengan bantuan mesin pembelajaran.

Berdasarkan penerapan algoritme J48 pada mesin pembelajaran WEKA diketahui bahwa parameter masukkan yang berpengaruh dalam pembentukan aturan pohon keputusan adalah sumber bahan baku dan sumber bahan tambahan dengan nilai akurasi aturan keputusan sebesar 99,3\%. Namun setelah dilakukan diskusi dengan pakar, dihasilkan informasi, parameter yang berpengaruh terdiri atas sumber bahan baku, titik kritis bahan dan proses tambahan, dan sumber bahan tambahan. Parameter yang ditetapkan oleh pakar memiliki keterkaitan dengan parameter yang dihasilkan dari penerapan algoritme J48, seperti titik kritis bahan dapat ditentukan berdasarkan sumber bahan baku dan proses tambahan sedangkan nilai atribut proses tambahan berkaitan dengan ada tidaknya penggunaan sumber bahan tambahan yang digunakan dalam suatu proses produksi.

Detail proses pembentukkan aturan penentuan keputusan yang dihasilkan dapat diketahui menggunakan bantuan perangkat lunak pengolahan data spreadsheet Microsoft Office Excel, dihitung menggunaan persamaan 1 dan 2 (Sahu dan Mehtre, 2015) dengan hasil penghitungan pada Tabel 1 dan 2 .

gain=info $(\mathrm{T})-\sum_{\mathrm{i}=1}^{\mathrm{s}} \frac{\left|\mathrm{T}_{\mathrm{i}}\right|}{|\mathrm{T}|} \times \operatorname{info}\left(\mathrm{T}_{\mathrm{i}}\right)$

$\mathrm{T}$ adalah set dan $\mathrm{T}_{\mathrm{i}}$ ( $\mathrm{i}=1$ to $\mathrm{s}$ ) adalah subset dari $\mathrm{T}$ yang terdiri dari nilai yang berbeda untuk atribut $\mathrm{A}$. info (T) diketahui sebagai fungsi entropy yang dideskripsikan pada persamaan (2) (Sahu dan Mehtre, 2015).

$\operatorname{info}(T)=-\sum_{j=1}^{N_{\text {class }}} \frac{\text { freq }\left(C_{j}, T\right)}{|T|} \times \log \left(\frac{\text { freq }\left(C_{j}, T\right)}{|T|}\right)$

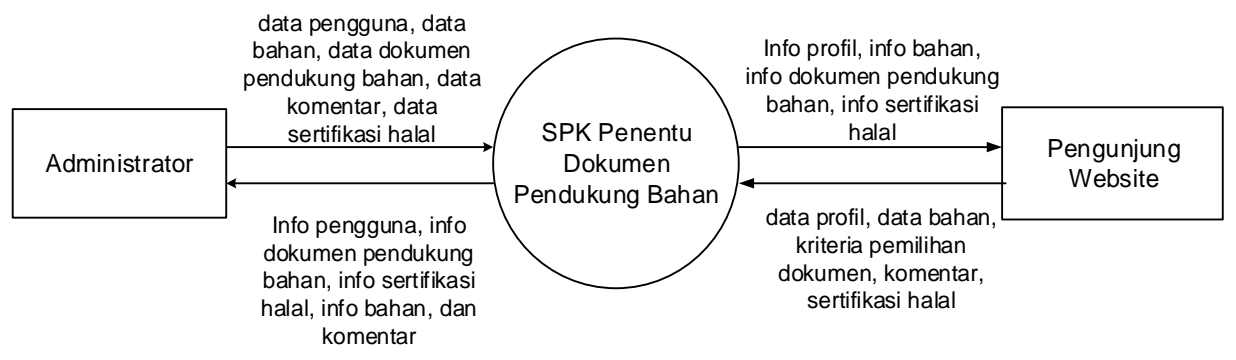

Gambar 2. Context diagram SPK PDPB

Tabel 1. Nilai gain parameter bahan

$\begin{array}{cccccc}\text { Proses } & \text { Sumber } & \text { Titik Kritis } & \text { Proses } & \text { Jenis Bahan } \\ \text { Iterasi } & \text { Bahan Baku } & \text { Taman } & \begin{array}{c}\text { Sumber Bahan } \\ \text { Tambahan }\end{array}\end{array}$

\begin{tabular}{lccccc}
\hline I1 & 0,199 & 0,080 & 0,007 & 0,006 & 0,169 \\
I2 (BT) & - & 0,005 & 0,003 & 0,066 & 0,418 \\
I2 (Mi) & - & 0,000 & 0,001 & 0,007 & 0,199 \\
I2 (SK) & - & 0,168 & 0,168 & 0,053 & 0,414 \\
I2 (Na) & - & 0,000 & 0,005 & 0,058 & 0,396 \\
\hline
\end{tabular}

Keterangan: I1 = nilai gain iterasi pertama; $\mathrm{I} 2(\mathrm{BT})=$ nilai gain iterasi ke-2 untuk parameter sumber bahan baku yang bernilai bahan tambang; $22(\mathrm{Mi})=$ nilai gain iterasi ke-2 untuk parameter sumber bahan baku yang bernilai bahan mikrobial; I2 $(\mathrm{SK})=$ nilai gain iterasi ke-2 untuk parameter sumber bahan baku yang bernilai bahan sintetik kimia; $22(\mathrm{Na})=$ nilai gain iterasi ke-2 untuk parameter sumber bahan baku yang bernilai bahan nabati. 
Tabel 2. Nilai entropy parameter bahan

\begin{tabular}{|c|c|c|c|c|c|c|}
\hline & \multirow{2}{*}{ Iterasi } & \multirow{2}{*}{ EI1 } & \multicolumn{4}{|c|}{ EI2 } \\
\hline & & & (BT) & (Mi) & (SK) & (Na) \\
\hline \multirow{5}{*}{ Sumber Bahan Baku } & B_tambang & 0,5 & - & - & - & - \\
\hline & Hewani & 0,0 & - & - & - & - \\
\hline & P_mikrobial & 0,2 & - & - & - & - \\
\hline & Sintetik Kimia & 0,4 & - & - & - & - \\
\hline & Nabati & 0,4 & - & - & - & - \\
\hline \multirow{8}{*}{ Titik Kritis Bahan } & B_aditif & 0,5 & 0,4 & - & 0,4 & 0,4 \\
\hline & B_pelarut & 0,4 & - & - & 0,4 & - \\
\hline & B_pengekstrak & 0,4 & - & - & - & 0,4 \\
\hline & B_pengisi & 0,0 & - & - & - & - \\
\hline & B_penolong & 0,5 & 0,4 & 0,0 & 0,4 & 0,4 \\
\hline & B_penyalut & 0,0 & - & - & - & - \\
\hline & Media fermentasi & 0,2 & - & 0,2 & - & - \\
\hline & Tidak/bukan bahan kritis & 0,0 & 0,0 & 0,0 & 0,0 & 0,0 \\
\hline \multirow{2}{*}{ Proses Tambahan } & Tidak & 0,3 & 0,0 & 0,0 & 0,0 & 0,0 \\
\hline & $\mathrm{Ya}$ & 0,5 & 0,4 & 0,2 & 0,4 & 0,4 \\
\hline \multirow{15}{*}{ Jenis Bahan Tambahan } & Antikempal & 0,3 & 0,3 & 0,3 & 0,3 & 0,3 \\
\hline & Antioksidan & 0,5 & 0,3 & 0,0 & 0,3 & 0,3 \\
\hline & Emulsifier & 0,5 & 0,4 & 0,2 & 0,4 & 0,5 \\
\hline & Flavor Enhancer & 0,5 & 0,5 & 0,2 & 0,4 & 0,4 \\
\hline & Gula_alkohol & 0,5 & 0,5 & 0,2 & 0,5 & 0,4 \\
\hline & Gum & 0,4 & 0,0 & 0,0 & 0,0 & 0,0 \\
\hline & Lain-lain & 0,5 & 0,4 & 0,2 & 0,4 & 0,4 \\
\hline & Pemanis & 0,4 & 0,0 & 0,0 & 0,0 & 0,0 \\
\hline & Pengatur keasaman & 0,4 & 0,3 & 0,0 & 0,3 & 0,3 \\
\hline & Pengawet & 0,5 & 0,3 & 0,0 & 0,3 & 0,3 \\
\hline & Pengental & 0,4 & 0,0 & 0,0 & 0,0 & 0,0 \\
\hline & Pengkilap & 0,4 & 0,3 & 0,3 & 0,3 & 0,3 \\
\hline & Pewarna & 0,5 & 0,5 & 0,0 & 0,4 & 0,4 \\
\hline & Stabilizer & 0,5 & 0,4 & 0,3 & 0,5 & 0,5 \\
\hline & Tidak & 0,3 & 0,0 & 0,0 & 0,0 & 0,0 \\
\hline \multirow{6}{*}{ Sumber Bahan Tambahan } & Bahan tambang & 0,4 & 0,0 & 0,0 & 0,0 & 0,0 \\
\hline & Hewani & 0,0 & 0,0 & 0,0 & 0,0 & 0,0 \\
\hline & Proses mikrobial & 0,3 & 0,0 & 0,0 & 0,0 & 0,0 \\
\hline & Sintetik kimia & 0,4 & 0,0 & 0,0 & 0,0 & 0,0 \\
\hline & Nabati & 0,4 & 0,0 & 0,0 & 0,0 & 0,0 \\
\hline & Tidak & 0,3 & 0,0 & 0,0 & 0,0 & 0,0 \\
\hline
\end{tabular}

Keterangan: $\quad$ EI1= nilai entropy iterasi pertama; EI2 $(\mathrm{BT})=$ nilai entropy iterasi ke-2 untuk parameter sumber bahan baku yang bernilai bahan tambang; EI2 (Mi)= nilai entropy iterasi ke-2 untuk parameter sumber bahan baku yang bernilai bahan mikrobial; EI2 $(\mathrm{SK})=$ nilai entropy iterasi ke-2 untuk parameter sumber bahan baku yang bernilai bahan sintetik kimia; EI2 $(\mathrm{Na})=$ nilai entropy iterasi ke-2 untuk parameter sumber bahan baku yang bernilai bahan nabati.

Nilai gain pada Tabel 1 dihitung mengunakan persamaan (1) untuk menentukan parameter yang menjadi root atau node pohon keputusan dalam pembentukan aturan dukungan keputusan, Jumlah iterasi yang dihasilkan dari penghitungan nilai gain adalah 2 kali iterasi. Nilai maksimum iterasi pertama pada Tabel 1 terdapat pada parameter sumber bahan baku, dengan demikian parameter tersebut terpilih menjadi root atau node awal yang paling berpengaruh pada pembentukan pohon keputusan. Posisi node tersebut dapat dilihat pada Gambar 3 di posisi teratas. Pada iterasi terakhir, yaitu iterasi ke-2 nilai maksimum terdapat pada parameter sumber bahan tambahan = bahan tambang, sumber bahan tambahan = bahan mikrobial, sumber bahan tambahan = bahan sintetik kimia dan sumber bahan tambahan = nabati. Dengan demikian dapat ditentukan node berikutnya atau child node pohon keputusan ditempati oleh patameter sumber bahan tambahan, Node yang terbentuk pada iterasi ke-2 ini dapat dilihat pada Gambar 4. Nilai enteropy pada Tabel 4 dapat 
dihitung menggunakan persamaan (2), ketika nilai entropy dari parameter sumber bahan baku = hewani berjumlah 0,0 dokumen pendukung yang ditunjukan adalah sertifikasi halal, maka telah dapat ditentukan kelas dari node sumber bahan baku = hewani. Jika nilai enteropy suatu parameter berjumlah 0,0 , kelas dari parameter tersebut atau node akhir dari parameter pohon keputusan tersebut sudah dapat ditentukan.

\section{Analisis Kebutuhan Sistem}

Analisis kebutuhan sistem bertujuan mendokumentasikan proses bisnis, memahami kebutuhan yang diperlukan dalam perancangan sistem dan mempermudah proses perancangan dan implementasi sistem, Sistem yang dibangun pada penelitian ini disebut SPK PDPB, merupakan akronim dari Sistem Pendukung Keputusan Penentuan Dokumen Pendukung Bahan. Sistem ini memiliki input berupa nama-nama bahan yang merupakan komposisi dari suatu produk. Data input tersebut selanjutnya diproses menggunakan 43 aturan keputusan sebelum menghasilkan output berupa informasi jenis dokumen pendukung dari bahan yang diinputkan, SPK PDPB ini merupakan sistem berbasis web yang dikembangkan menggunakan bahasa pemrograman PHP dan database management system MySQL. Sistem ini bermanfaat untuk membantu mempermudah pengguna (pengunjung website), menentukan dokumen dalam proses pengisian data bahan saat mengajukan sertifikasi halal. Selain itu, pengunjung website juga dapat melakukan pencarian informasi bahan dan sertifikasi halal.

SPK PDPB terdiri dari 2 level hak akses pengguna, yaitu pengguna administrator dan pengunjung website (perusahaan yang akan mengajukan sertifikasi halal). Administrator merupakan pengguna yang memiliki hak akses penuh dalam menggunakan semua fungsi pada sistem, termasuk fungsi yang dapat diakses oleh pengunjung website. Pengunjung website hanya memiliki hak akses untuk melakukan pencarian informasi bahan, jenis dokumen pendukung bahan, sertifikasi, menentukan pemilihan dokumen pendukung bahan, melihat riwayat pemilihan dokumen yang pernah dilakukan, dan meninggalkan komentar pada website.

\section{Kebutuhan Perangkat Keras dan Perangkat Lunak Sistem}

Pada penelitian ini perangkat keras dan perangkat lunak yang digunakan sebagai penunjang pembangunan sistem, diantaranya laptop dengan spesifikasi ASUS A455LD, Intel(R) Core(TM) i54210U CPU @ 1,70 GHz (4 CPUs), 2,4 GHz 64bit, Random Access Memory 4 GB, Harddisk 500 GB, Video Graphic Adapter NVIDIA Geforce 820M 2 GB, sistem operasi Windows 8,1 Pro, basis data MySQL versi 5,0,51b, bahasa pemrograman PHP versi 5,2,6, perancangan antar muka Balsamiq Mockups 3, pengolah skrip Sublime 3, pengolah citra Adobe Photoshop CS4, perancangan sistem Visio 2016, serta desain model Weka 3,6,12.

\section{Diagram Alir Data dan Basis data Sistem}

Analisis aliran data pada sistem dilakukan dengan dekomposisi context diagram ke dalam DFD yang menggambarkan proses secara detail, Pada DFD terdapat dua hak akses pengguna, administrator dan pengunjung website. Pengguna harus melakukan proses login untuk dapat mengakses proses lainnya. Proses login memiliki dua aliran data masuk, yaitu username dan password, dan satu aliran data keluar, yaitu beranda sistem, sedangkan untuk mengakhiri seluruh sesi proses harus melakukan proses logout.

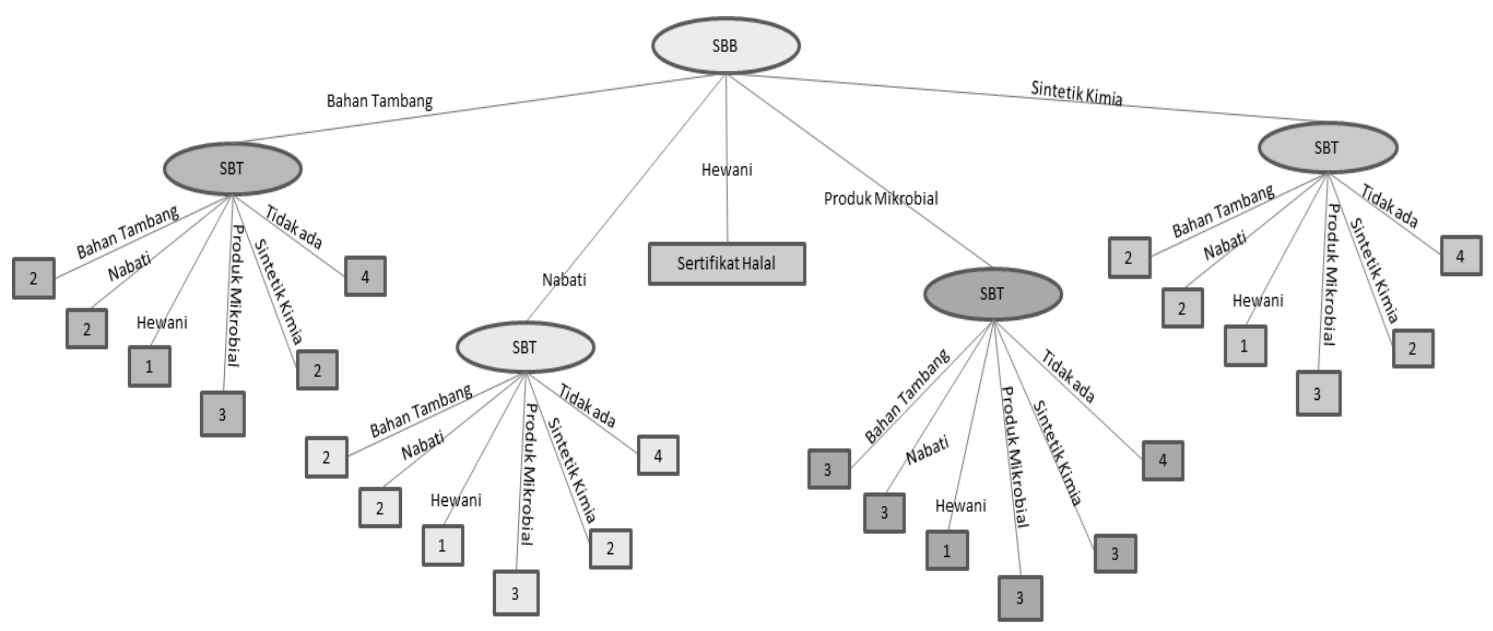

Keterangan: $\mathrm{SBB}=$ sumber bahan baku; $\mathrm{SBT}=$ sumber bahan tambahan; $1=$ sertifikat halal; $2=$ diagram alir proses dan spesifikasi teknis; 3 = diagram alir proses atau spesifikasi teknis atau sertifikat halal jika menggunakan bahan aditif atau penolong yang kritis; $4=$ tidak perlu dokumen pendukung

Gambar 3. Model aturan penentuan keputusan 


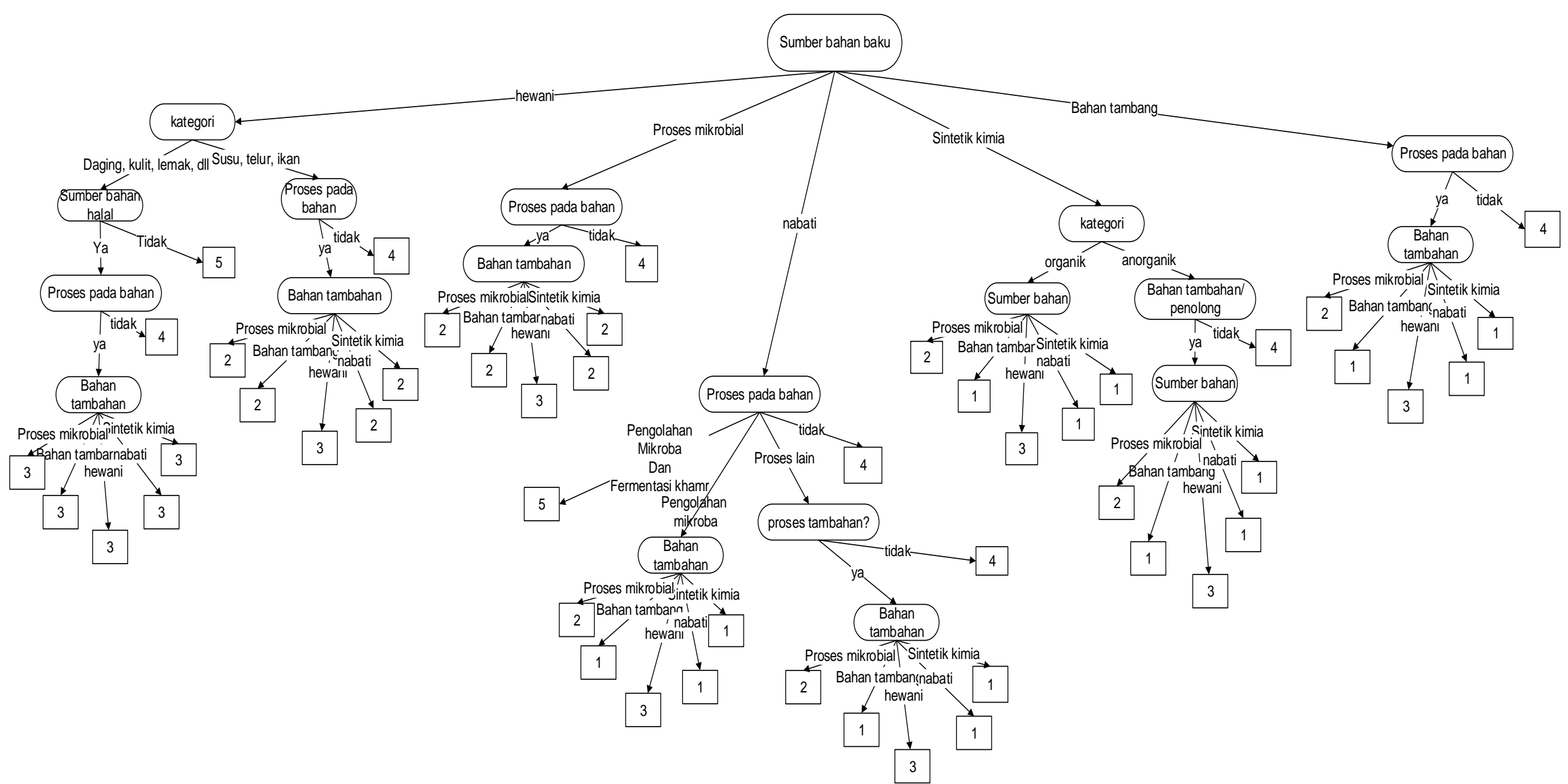

Keterangan: $1=$ diagram alir proses dan / atau spesifikasi teknis; $2=$ diagram alir proses atau spesifikasi teknis atau sertifikat halal jika menggunakan bahan aditif atau penolong yang kritis; $3=$ sertifikat halal; $4=\mathrm{COA}$ (sertifikat analisis) / dokumen pembelian bahan; $5=$ tidak dapat digunakan / haram

Gambar 4 Model pohon keputusan SPK penentu dokumen pendukung bahan 
Perancangan basisdata sistem dilakukan dengan membuat entity-relationship diagram (ERD), ERD terbentuk dari analisis terstruktur yang digunakan untuk menunjukan adanya hubungan objek yang saling berpengaruh dan selanjutnya dapat digunakan sebagai penghasil informasi pada suatu aplikasi. Basisdata SPK PDPB ini terdiri atas satu tabel utama/transaksi dan tabel referensi (tabel data pengguna, bahan, titik kritis bahan, sumber bahan baku, sumber bahan tambahan, proses tambahan, dokumen pendukung, riwayat pemilihan dokumen, sertifikasi halal, dankomentar). Perancangan basisdata tersebut dapat dilihat pada Gambar 5.

\section{Perancangan Antarmuka Sistem}

Perancangan antarmuka sistem bertujuan untuk memperjelas kegunaan dan tujuan dari sistem sehingga dapat mempermudah tahap implementasi sistem. Perancangan antarmuka terdiri dari tampilan masukan dan keluaran yang didokumentasikan menggunakan software Balsamiq Mockups 3 . Gambar 6 adalah contoh perancangan halaman masukkan parameter pemilihan dokumen pendukung bahan yang dirancang untuk diakses oleh pengunjung website yang melakukan proses login.

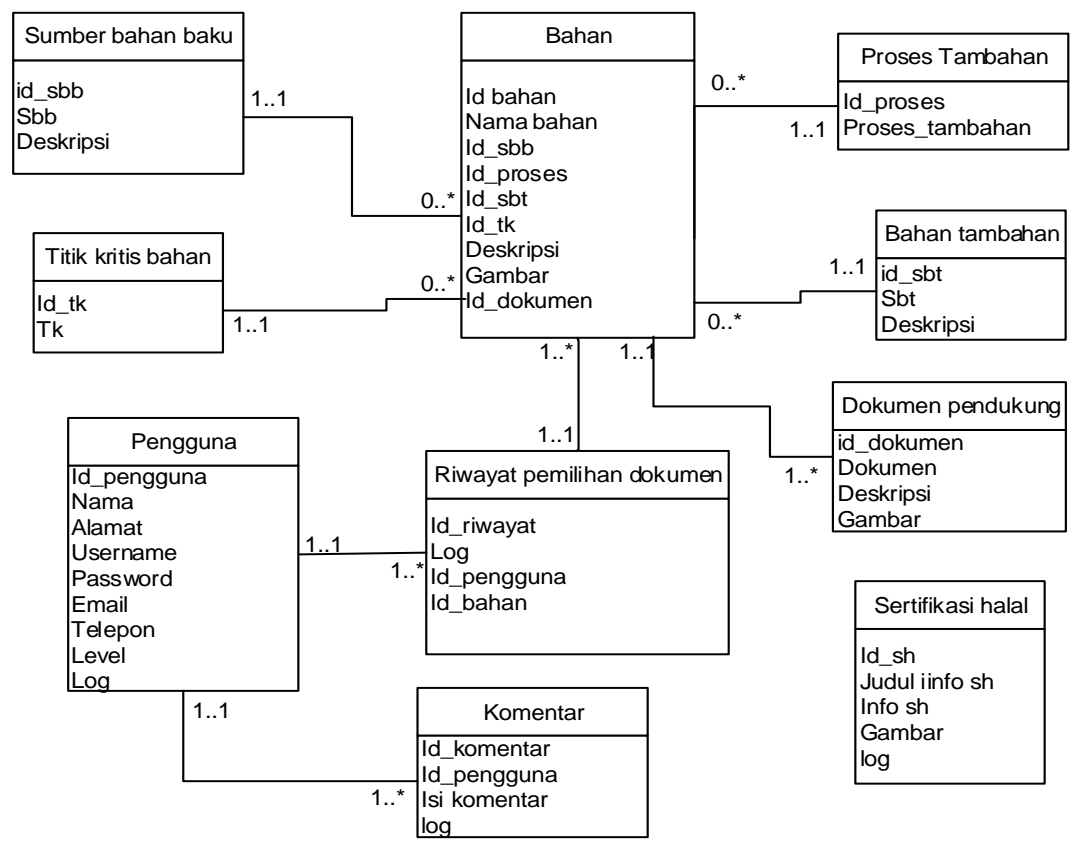

Gambar 5. Perancangan Basisdata

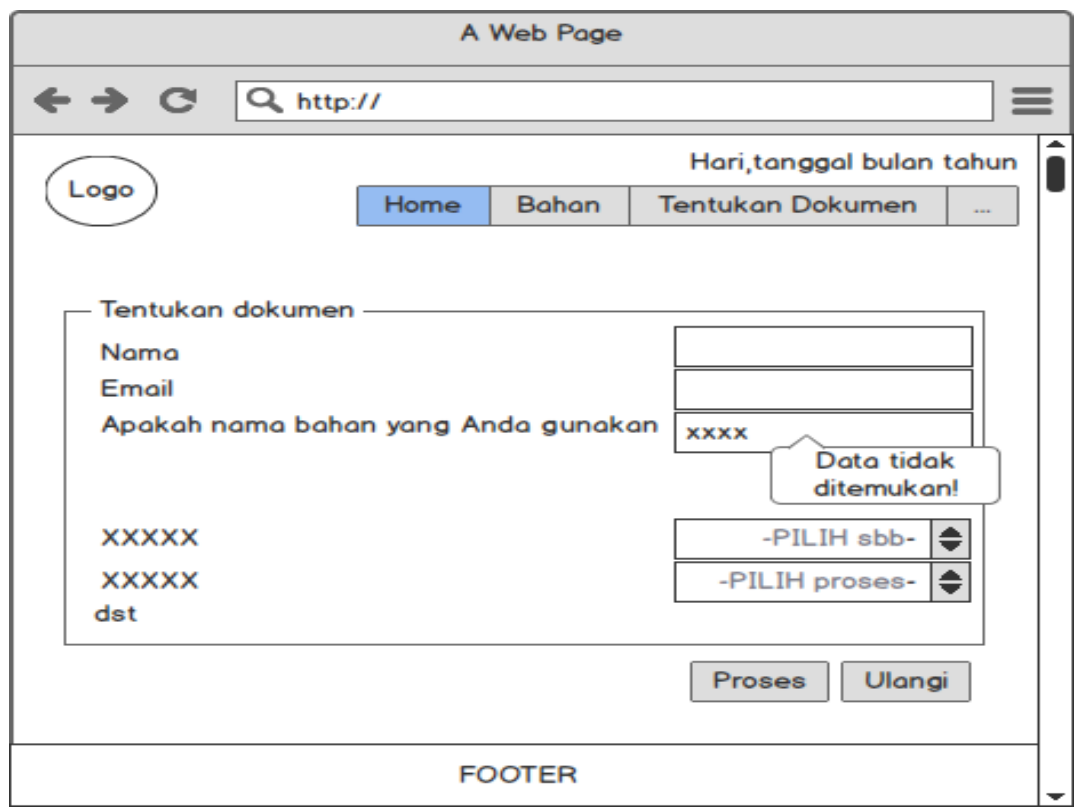

Gambar 6. Antarmuka form masukan parameter pemilihan dokumen pendukung bahan 


\section{Implementasi Sistem}

Tahap implementasi sitsem merupakan tahap penerapan hasil analisis dan perancangan kedalam sistem berbasis website yang dapat digunakan langsung oleh pengunjung website. Implementasi sistem dilakukan dengan menggunakan bahasa pemrograman PHP dan basisdata MySQL. Menu utama pada SPK PDPB ini adalah menu "Tentukan Dokumen". Pengunjung website diminta memasukkan parameter-parameter mengenai bahan yang digunakannya untuk mendapatkan informasi mengenai dokumen pendukung yang diperlukannya dalam memenuhi persyaratan pengajuan sertifikasi halal MUI. Informasi yang dikeluarkan nantinya merupakan implementasi dari model aturan penentuan keputusan yang telah dijelaskan sebelumnya. Implementasi halaman penentuan dokumen pendukung bahan dapat dilihat pada Gambar 7 .

\section{Pengujian Sistem}

Pada tahap pengujian sistem dilakukan pengujian fungsional terhadap sistem yang telah diimplementasikan. Pengujian dilakukan menggunakan metode black box testing, dengan memberikan suatu masukkan pada skenario uji dan selanjutnya diamati kesesuaian hasil yang ditampilkan oleh sistem dengan hasil yang diharapkan. Aktivitas pada skenario uji meliputi proses menambah, mengubah dan menghapus data, melakukan pencarian data dan menetukan dokumen pendukung bahan. Tahap verifikasi dilakukan menggunakan kuesioner kepada 12 responden yang merupakan Auditor LPPOM-MUI dengan masingmasing responden diberikan 10 nama bahan yang harus ditentukan jenis dokumen pendukungnya. Selanjutnya dilakukan penyesuaian antara hasil kuesioner dengan hasil yang ditampilkan sistem. Hasil verifikasi data tersebut selanjutnya menjadi acuan perbaikan data yang tersimpan pada basisdata.

\section{Kesimpulan dan Saran}

\section{Kesimpulan}

Parameter yang tepat untuk menentukan keputusan dokumen pendukung bahan yang diperlukan pada pengajuan sertifikasi halal adalah sumber bahan baku, sumber bahan tambahan, titik kritis bahan dan ada/tidaknya proses tambahan pada bahan yang digunakan. Penetapan parameter tersebut juga bergantung pada pendapat pakar. Parameter tersebut selanjutnya diimplementasikan ke dalam website dinamis dengan masukkan berupa nama bahan dan keluaran berupa jenis dokumen pendukung (sertifikat analisis, diagram alir proses, spesifikasi teknis, sertifikat halal, dokumen pembelian bahan atau tanpa dokumen) dari bahan yang dimasukkan pengguna. Sistem pendukung keputusan penentuan dokumen pendukung bahan diuji menggunakan metode pengujian black box dan disimpulkan bahwa sistem dapat berfungsi sesuai dengan kasus uji dan hasil yang diharapkan. Sistem juga dapat berjalan dengan baik pada peramban web Google Chrome, Mozilla Firefox, dan UC Browser.

Sistem PanाTाTाII) Keputusan
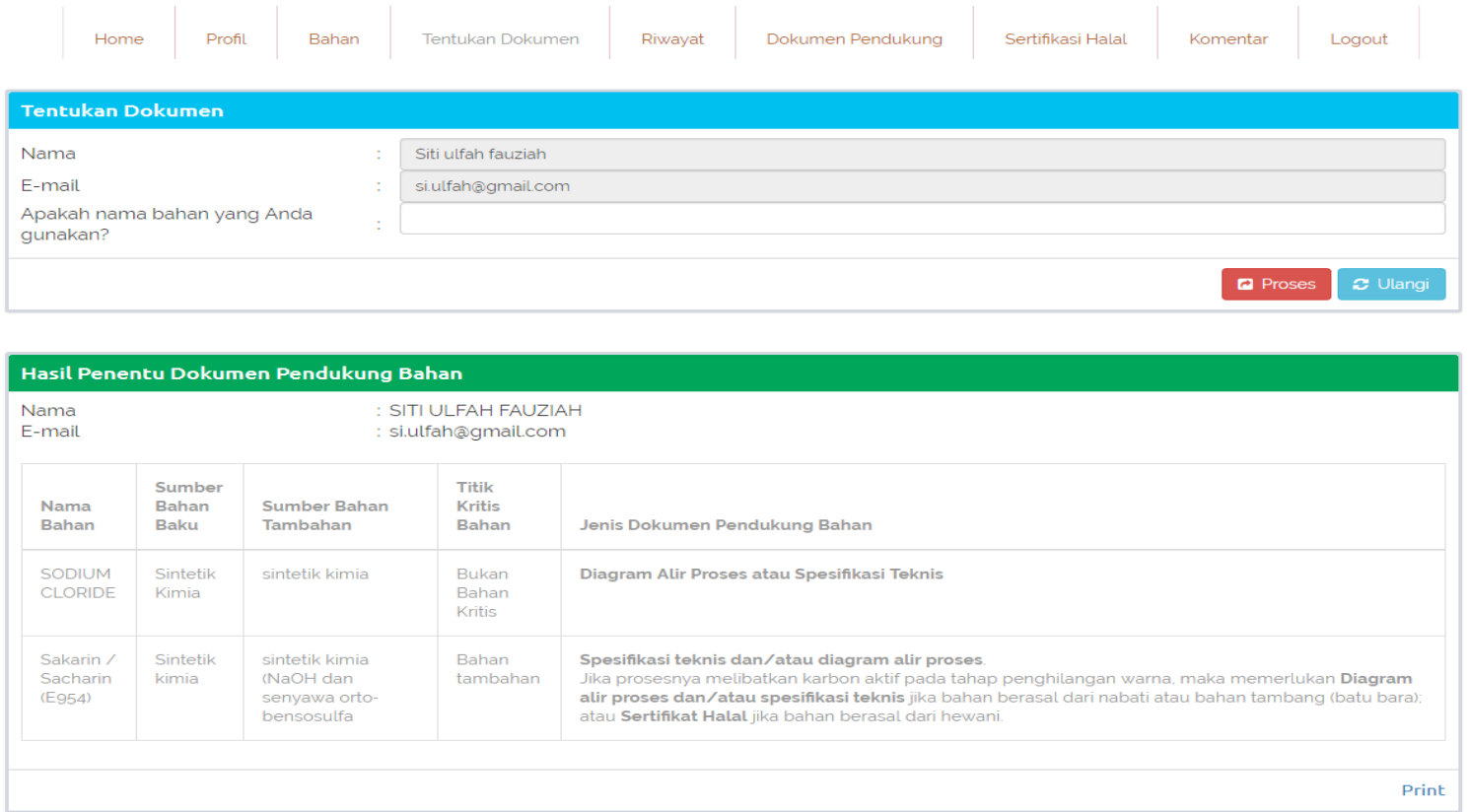

Gambar 7. Implementasi penentuan dokumen pendukung bahan 


\section{Saran}

Parameter penentuan dokumen pada sistem yang ada saat ini hanya berfokus pada ada atau tidaknya proses pada bahan. Diharapkan kedepannya dapat mencakup parameter proses pengolahan bahan secara detail, nama proses, bahan tambahan dan bahan penolong yang digunakan pada proses tersebut.

\section{DAFTAR PUSTAKA}

Abu AB, Ali ZO, Zakree MAN, Razak AH, Mohd HS, Alyani KB, Natasyah FAH. 2013. Classification of halal status for food product using data mining approach. Advances in information Sciences and Service Sciences. 5(15):42-59.

Ahsyar TK, Seminar KB, Hermadi I, Suyatma NE. 2015. Decision support system for selecting of meat product packaging. International Journal of Information Technology and Business Management.42(1): 17-24.

[BPS] Badan Pusat Statistik. 2015, Statistik Politik 2015. Katalog BPS $=4601003$ [Internet], Jakarta(ID): Badan Pusat Statistik, JakartaIndonesia, [diunduh 2015 Des 31 Tersedia pada: $\quad$ http://www,bps,go,id/websitel pdf_publikasi/Statistik-Politik-2015,pdf [20 Maret 2016].

Fauzi AS, Hidayah NA, Kumaladewi N. 2014. Eservice system design in registrating certification and presentating halal product information on the Indonesian Olema Council (Case study: Indonesian Olema Council (MUI) Bogor Regency), Cyber and IT Service Management, 2014 International Conference. Tangerang Selatan, Indonesia: 16 Feb 2015.

E-Halal Registration. 2014. [diunduh 2015 Nov 2], Tersedia pada: http://.www.halalmui.org/
Hanum HM, Bakar ZA, Rahman NA, Rosli MM, Musa N. 2012. Using topic analysis for querying halal information on Malay documents, International Halal Conference, Kuala Lumpur, Malaysia. Kuala Lumpur, Malaysia: 4-5 Sep 2012.

Iberahim H, Kamaruddin R, dan Shabudin A. 2012. Halal development system $=$ The institutional framework, issues and challenges for halal logistics, In Business, Engineering and Industrial Applications (ISBEIA). Bandung, Indonesia: 23-26 Sep 2012.

Marimin dan Maghfiroh N. 2013. Aplikasi Teknik Pengambilan Keputusan dalam Manajemen Rantai Pasok. Bogor (ID): IPB Press.

Moussa M, Ruanpura JY, Jergeas G. 2004. Decision tree module whitin support simulation system. Proceedings of the 2004 winter. Washington DC, USA: 5-8 Des 2004.

Rajagopal S, Ramanan S, Visvanathan R, Satapathy S. 2011. Halal certification = implication for marketers I UAE. Journal Islamic Marketing. 2 (2): 138-153.

Sahu S dan Mehtre BM. 2015. Network intrusion detection system using J48 decision tree. International Conference on Advances in Computing, Communications and Informatic. Kochi, India: 10-13 Ags 2015.

Salehudin I dan Mukhlish BM. 2012. Pemasaran Halal: Konsep, Implikasi dan Temuan di Lapangan, Jakarta (ID): Lembaga Penerbit Fakultas Ekonomi UI.

Samsi SZM, Zainal NZ, dan Ibrahim O. 2011. Information quality model for halal online business. Research and Innovation in Information Systems (ICRIIS). 2011 International Conference. Kuala Lumpur, Malaysia: 23-24 Nov 2011.

Tieman M. 2011. The application of halal in supply chain management: in-depth interviews. Journal of Islamic Marketing. 2(2): 186-195. 